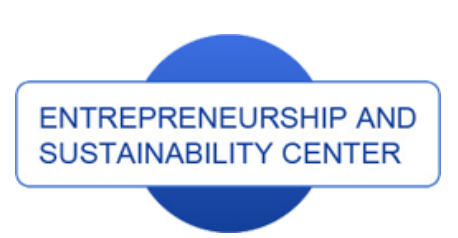

Publisher

http://jssidoi.org/esc/home

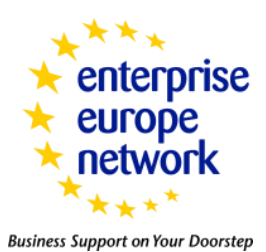

CASPA

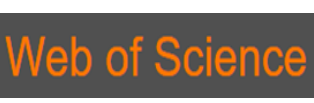

Clarivate

\title{
ANALYSIS OF THE DEVELOPMENT TERMS OF THE RADIO MARKET IN THE SLOVAK REPUBLIC *
}

\author{
Michal Fabuš ${ }^{1}$, Marcel Lincényi ${ }^{2}$ \\ 1,2 Department of Economics and Finance, Economics and Management Institute, School of Economics and Management of \\ Public Administration in Bratislava, The Slovak Republic
}

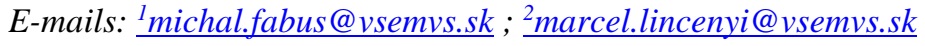

Received 18 May 2018; accepted 15 October 2018; published 30 December 2018

\begin{abstract}
The radio market in the Slovak Republic is characterized by the introduction of a dual system that brings the market environment of supply and demand after the change of social conditions after 1989. Since the main source of funding for commercial radio stations and partial revenues of public radio stations is revenue from the sale of advertising space, their main objective is to maximize their share of the results achieved (the number of listeners and the total market share) from advertising within the ad. The main objective of the presented research study is to analyze the development trends of selected Slovak broadcasters in the monitored period 2011-2015, focusing on the analysis of the listening volume and the amount of financial resources spent on advertising for selected Slovak radios in the Slovak Republic.
\end{abstract}

Keywords: radio stations; broadcast; market development; market of radio stations; analysis; advertising amount

Reference to this paper should be made as follows: Fabuš, M.; Lincényi, M. 2018. Analysis of the development terms of the radio market in The Slovak Republic, Entrepreneurship and Sustainability Issues 6(2): 591-602. http://doi.org/10.9770/jesi.2018.6.2(9)

JEL Classifications: M21, Y80

Additional disciplines: political sciences, sociology, information and communication

\footnotetext{
"The paper is the output of a scientific project IGA no. 3/2017 „, Development of international business and international management in the conditions of globalization" (Funder: VSEMvs IGA VSEMvs, i.e. School of Economics and Management in Public Administration)
} 


\section{Introduction}

The size of the radio market can be analyzed based on two fundamental aspects: share of listening to radio (audience rate) and the amount of advertising placed in the broadcast. For television and radio media, the "audience rate" indicator is used, which represents the proportion of viewers and listeners watching individual programs in the 15-minute interval. (Kita, 2010, p. 351; Dul'ová Spišáková et al. 2017) "In general, the advertiser is interested in the audience, which tells how many people are watching the station when the advertisement is broadcast." (Burton, Jirák, 2001, p. 322) serve as a warning signal to avoid a radio station if it does not want to lose its listeners, or vice versa, how to keep it up for its listening. When analyzing listening, it is advisable to develop each of the selected radios separately, to find the most important events that have influenced the development of the radio and then to see the radio market in a comprehensive way.

Tracking of ad volume may be important for listeners in the form of physical and legal persons who are potential advertisers on that radio. "Advertisers are scheduled to adhere to complex criteria from advertisers with the aim of maximizing the revenue for the company." (Toth, Mura, 2014)

The radio market in the Slovak Republic during the financial and economic crisis (Toth, Mura, 2014) recorded an economic recession and a decline in marketing investments (Poliačiková, 2017, Mura et al. 2017). As noted by Patrik Groma (2016, p. 55), investment in the advertising market in Slovakia in 2010 (in the time of the crisis) has fallen by half compared with 2008 when it was greatest. Even from the above, we were interested in the development of the radio market in the Slovak Republic in recent years.

\section{Methodology}

We have divided the research model into a pre-empirical phase (research area, topic, objectives of investigation, research questions) and the empirical phase (data collection, data analysis, and answer to the questions). The design of the research area and the research topic can be defined as follows.

Research area: selected national radio broadcasters in the Slovak Republic.

Research topic: determinants of the market share of selected Slovak radio stations in the Slovak Republic.

The main objective of the presented research study was to analyze the development trends of the selected Slovak broadcasters in the monitored period 2011-2015.

The secondary research goal of the empirical part was to analyze the audience and volume of spent financial resources for advertising for selected Slovak radio companies in the Slovak Republic. The market share of the radio station and the number of listeners along with the coverage of the radio is the most important parameter for the advertiser. Based on this data, it is decided whether the volume of radio advertising investments in radio spots is the right choice, so it can bring the expected effect. It focuses on putting the ad in the broadcast to cover the area where it needs to reach out to potential customers and listen to the radio, then it can choose the most seamless option for itself, choose one radio station, deploy an advertisement to multiple radio stations, focus on nationwide coverage or only regionally. The advertising space of the radio can select and have price lists where the client can choose what he needs.

In the case of further planning and research, we prioritized the concept of research questions prior to identifying research problems, as recommended by Keith F. Punch (2008, p. 29). We identified one major research question (VO) that we have developed on three other specific research questions: 
The main research question: What were the developmental trends of the market of selected Slovak radio stations in the Slovak Republic during the monitored period 2011-2015?

Specific question: What is the development of listening to selected Slovak radio stations in the monitored period 2011 to 2015 ?

Specific question: What was the development of the advertising volume in selected Slovak broadcasters between 2011 and $2015 ?$

Research base: There are currently 41 radio stations and radios in Slovakia that have allocated frequencies for broadcasting via terrestrial broadcasters and the Internet, including nationwide, multiregional, regional and local radio stations. Due to the extensive research file, we decided to focus on the 5 most popular 5 Slovak radio stations: Radio Expres, Radio Slovakia, Radio Fun, Europa 2 radio and Fine radio, based on the Median SK survey $^{\dagger}$, which was held in 2016.

Several research methods have been used to investigate the problem. Data collection was obtained by analyzing the audience. Data is processed based on available surveys, TNS Slovakia, Ltd., which, within the framework of its activity, is conducting monitoring of advertising expenses at radio stations or a national MML-TGI survey of MEDIAN SK, which monitors the listening frequency of radio stations in several annual waves surveys conducted on the sample of respondents aged 14-79 years. This research sample is always in a different number, in the analyzed years ranged from 4076 to 4385 respondents.

Data was further analyzed by statistical methods (statistical average, time series analysis) and comparative methods. When analyzing time series, the most commonly used graphical method is used. This graphical analysis is important, for example, for preliminary data analysis. It is easy to read the basic information about development and to reflect this data (Koval'ová, Kulčár, 2017). The most commonly used chart for such an analysis is the line graph. It is composed of two axes - a horizontal one on which the time variable is located and the vertical one, on which the time series values are located. In addition to this graph, you can also use a column graph. (Rublíková, Př́hodová, 2008, Cseh Papp et al., 2018).

The basic characteristics of time series are divided into two large groups. The first are the descriptive characteristics (diameters) and the second are the rates of dynamics. Determining the average time value may be important for some analyzes. The dynamics rate plays a major role in characterizing the basic features of the timeline development. We will use a simple chronological average for the analysis.

\section{Result and Discussion}

Based on the analysis of the development trends of selected Slovak broadcasters in the Slovak Republic during the monitored period 2011-2015, the following conclusions can be drawn:

The top market share in all the monitored periods was Radio Expres, which reached 19.3\% market share in 2011, and it is interesting to note that this position has been defended despite its lowest share among these years. Behind it was Radio Slovakia with $16.6 \%$ and $3.3 \%$ less, with the result of $13.3 \%$ of the market share being Fun Radio. Below the $10 \%$ threshold, with $8.4 \%$, Radio Gentle was placed in the penultimate position, with Radio Europe 2 having the smallest share of analyzed radios with $6.7 \%$.

The year 2012 brought the three radio stations an increase in their share compared to the previous year. Radio Expres has improved and finished with the highest share of $19.5 \%$. Although with $2.6 \%$ downward versus Radio 
Expres, the second-best position was again defended by the public service Radio Slovakia with 16.9\%. Decrease compared to 2011 recorded the Fun Radio by up to $0.8 \%$ and reached a market share of $12.5 \%$. This was one of the biggest surprises this year, as this radio has not recorded such a year-long decline in its history. Similarly, the fourth position was defended by the Jemné radio with the same market share as last year, and although Radio Europe ended fifth as a fifth, it achieved the highest year-on-year increase by $0.9 \%$ and its share of $7.6 \%$ in the radio market.

In 2013, the order also did not change, and the numbers were very similar to the previous year. The same share and therefore 3rd place occupied Fun Radio, which defended its last year's share of $12.5 \%$. Other radios have experienced year-on-year decreases ranging from 0.1 to $0.5 \%$, which can be considered as minimum deviations. The year 2014 was somewhat more interesting when comparing the results, as the leader of the Radio Expres market reached almost 20\%, as well as Radio Slovakia with a year-on-year increase of up to $1.4 \%$ and $17.8 \%$. The opposite and falling trend was recorded by Fun Radio, which dropped to 11.8\%. Radio Europe 2 and Fine remained at the same level of the previous year.

In 2015 , the watched radios fell again, though only by 0.1 to $0.4 \%$, but we can say that no other radio did not endanger its position until it was noticed that this fall was shifting radio Europe 2 and Gentle there remains a minimal difference between them, and their next development will certainly be interesting to follow.

A summary of the development of the radio market in Slovakia and their share was also recorded through Figure 1 , whereby we are also able to visualize the situation on the radio market in the period under review.

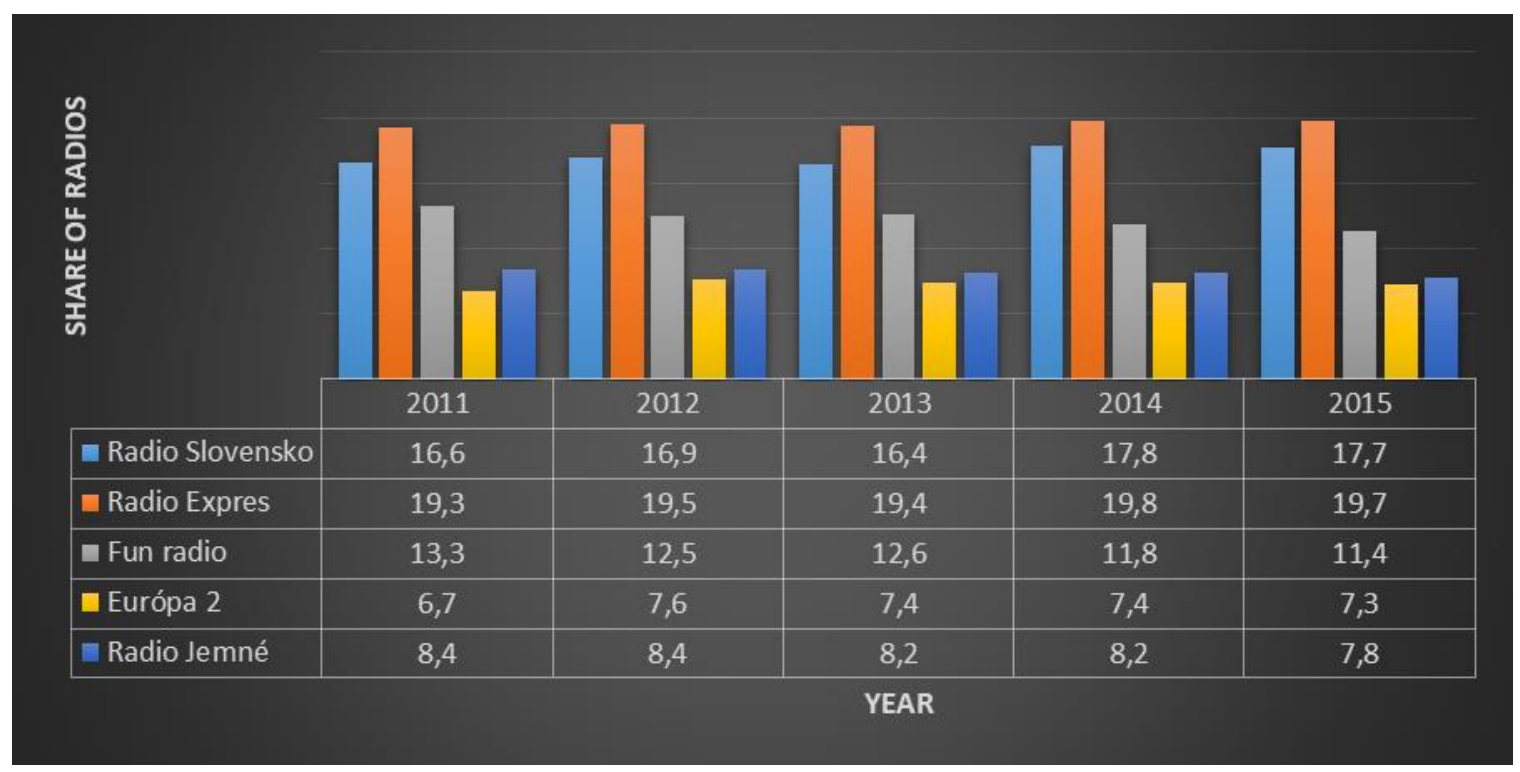

Fig. 1. Radio market share report $2011-2015(\%)$

Source: Processed from the results of the MML-TGI National Survey of MEDIAN SK

Based on the analysis of the listening of selected Slovak radio stations in the Slovak Republic in the monitored period 2011 to 2015, the following conclusions can be drawn: 
Radio Expres reached the highest average daily listening rate in 2011, when the number of listeners was less than 870,000 , Slovakia was the closest to the top radio with the number of listeners 746,573. About 150,000 less listeners had Fun Radio, below 600,000. Approximately the same distance in number of listeners was followed by the Jemné radio, which reached just over 377 thousand listeners that year, and the youngest radio of the monitored - Radio Europe 2 listened to an average of over 300 thousand listeners.

The year 2012 was successful for some radio stations, including the first Radio Expres, when its number of listeners jumped to 881 thousand, and Slovakia could be happy with an increase of 14 thousand listeners. The decline of the radio market we recorded in 2012 was associated with a significant drop in audience of more than 30,000. The exact opposite was the radio Europe 2, which during the year could convince its qualities up to 345,019 listeners, which was an incredible jump among all radio stations this year, as the increase was up to 45,000 new listeners compared to the previous year. There was almost no change in the number of listeners in Radio Delight, although the minimum increase of less than a thousand listeners could not be overlooked. 2013 was a declining one, as each of the radio stations surveyed experienced a drop-in listener, and none of them could stand in the way. Radio Slovakia lost less than 30 thousand, Radio Expres by about 15 thousand, Fun radio with at least 300 listeners and Radio Europe 2 and Fine by about 15 thousand listeners. However, this loss did not cause this radio socket to endanger another radio, or some of them would be pushed to the bottom of the radio.

The year-on-year results were significantly better in 2014, when the first public radio circuit, Slovakia's radio recorded a record year-on-year increase of its listening base, by as little as 65,000 listeners, and it was the highest number since 2011. Of course, that in the past has reached more numbers and the possibility of broadcasting through commercial stations has significantly weakened its market position, we perceive this positive shift as a breakthrough. Radio Expres has improved by less than 20,000 listeners, but Fun Radio has dropped down to nearly 40,000 listeners, and we have been able to track its dramatic weakness in the percentage assessment as well. Radio Europe 2 and Delice defended their figures and we did not notice any significant differences compared to the previous year.

The year 2015 was influenced not only by increased listening to other national and non-radio watchers, but also by a great upheaval in the radio market, when NRSR MPs approved an amendment to the Act on Mandatory Quotas for Slovak Music. Radio, even though the law came into force only in 2016, it had to adapt to this unsuitable situation and gradually change its broadcast and its structure. And since the listener was accustomed to his favorite radio, he was given the opportunity to prefer it and wanted a program better for radio that played other than Slovak songs. This boom was temporary because, ultimately, the obligation to play at least 20 percent of Slovak production in 2016 and 2017 at least 25 percent will have to be met by all Slovak commercial radio stations. Public radio and its channels have these percentages increased first to $30 \%$ and later to at least $35 \%$. Another condition of this law is to play these songs in the 6th to 24th hours, that is, at times when the listener has no chance to avoid them and the radio to fulfill this duty during the night broadcast, when the listening radios are logically the lowest.

We can therefore blame the decline of the Slovak Radio by about 10,000 listeners, as well as the 20,000-pound decrease of Radio Fun as well as the Fine Radio. In approximately the same numbers, only Radio Expres and Europe 2 were moving.

An overview of listening for the 2011-2015 reference period is shown in Figure 2 and contains the exact figures for the number of listeners in each year. 


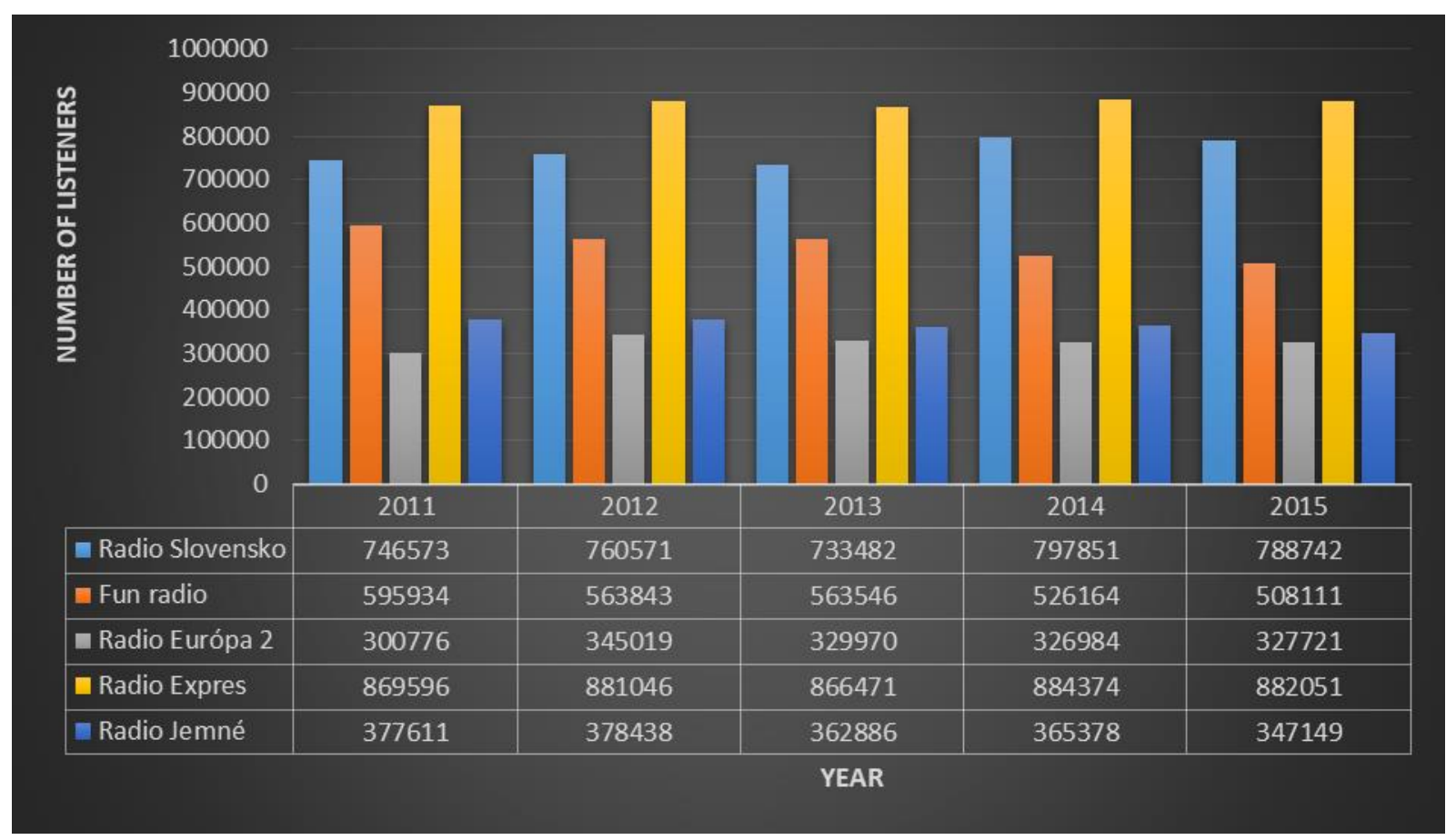

Fig. 2. Radio listening report 2011-2015 (in audience count)

Source: Processed from the results of the MML-TGI National Survey of MEDIAN SK

Based on the analysis of the volume of advertising in selected Czech broadcasters in the years 2011 to 2015, the following conclusions can be drawn:

In 2011, less than $€ 77$ million was spent on radios on the radio. It was no surprise that the biggest share of this volume went to Express, which had the highest market share that year. He sold more than $€ 23.5$ million for his ad sales. The second largest amount was attributed to Fun Radio, and it was less than 19 million euros. An interesting fact compared to these two radios is that even though Fun Radio broadcasts up to 400 hours of commercials and Radio Expres only around 300, there is a significant difference in the profits of these radios. Radio Expres reached $30.7 \%$ of the volume of advertising and Fun radio a little less, and $24.7 \%$. In smaller numbers the other 3 watched radios moved. Through them, much less money has been invested. The third on the ladder was the Gentle Radio, which sold over 7,5 million Euros of advertising space, the Public Radio of Slovakia for nearly 7,4 million Euros and the least received radio Europe 2 and less than 5,8 million Euros. These investments have also determined the proportion of radio advertising with the result of Radio $10 \%$, Radio Slovakia $9.6 \%$ and Radio Europe 2 with $7.5 \%$.

The increase in advertising revenue recorded total radio stations in 2012 by EUR 4.3 million compared to the previous year. When comparing the watched radios with the previous period, we can also see how radios were developing in this direction. The biggest surge in investment was surprisingly by the Delight radio by $15.3 \%$, the Radio Express by more than $12 \%$, the Fun radio had to be satisfied with a 5\% increase. Radio Slovakia also sold more than $1.4 \%$ of the advertising space, with some increase without price changes, nor can it be expected, because it has a legally defined advertising space that it can sell, and it does not have much space in comparison to commercial radios. This year, the only radio recorded a decrease in the volume of advertising Europa 2 radio by $-2.3 \%$. 
The International Journal

ENTREPRENEURSHIP AND SUSTAINABILITY ISSUES

ISSN 2345-0282 (online) http://jssidoi.org/jesi/ 2018 Volume 6 Number 2 (December) http://doi.org/10.9770/jesi.2018.6.2(9)

The decline in the amount of radio advertising investment was recorded in 2013. The year-on-year decline was $4.4 \%$, after a decrease of 3.6 million euros. Surprisingly, Radio Slovakia recorded an increase of 3.8\%, followed by Radio Expres $+0.8 \%$, the other radios received year-on-year minus numbers. Radio Europe 2 in this direction decreased by $-6.6 \%$, Radio Delicate by $-6.1 \%$, Radio Fun by $-4.8 \%$. Even after these year-on-year changes, however, there was no change in the percentage of the volume of radio advertising. For the third year, Radio Expres has the largest volume of $34.49 \%$ and the highest in the current reporting period. Fun radio reached 24.24\%, Radio Delicate Less than 11\%, Radio Slovakia kept its average level at $9.9 \%$ and Europe 2 again the smallest share $6.82 \%$.

The year 2014 already indicated an upward trend and a positive development for some radios. Total spending on the media has finally exceeded 1 billion and has also been reflected in radio advertising, but in reallocating to individual radio stations. Fun Radio has sold its ad space with the highest ever increase $+24.23 \%$, still a still newcomer to the Gentle $+10.42 \%$ radio. The curve of other radios had a decreasing tendency. Radio Slovakia dropped by $-5.39 \%$ and compared to 2013 by about 400 thousand euros. Radio Expres went down by 1.2 million, a drop of $4.36 \%$, only Radio Europe 2 remained stable. In the stock, Fun Radio was the most significant player, gaining 33\% market share, but still the second best, Radio Expres did not jump with its 36.15\%. Overall, the other radios also had a higher share this year. Radio Slovakia reached over 10.3\%, Radio Mere over 13\% and Europa2 almost $7.5 \%$.

In the period under review, the year of 2015 was the most investment-intensive year. Almost 1.3 billion euros were invested in advertising, and radio stations were also pleased. The year-on-year increase in investments from suppliers exceeded the plus value of $+16.7 \%$, and it was purely from the sale of radio advertising. Once again, the largest share of advertising is attributable to Radio Expres in 2015, and more than 35\%, Fun Radio sold its space by more than $4.5 \%$ year on year, Radio Slovakia up $22.47 \%$. Maybe the link to radio sales through radio services has caused an enormous increase in profits from the sale of advertising via Gentle Radio - up to + $40.44 \%$ year on year, as was Radio Europa 2 with an increase of $+6.44 \%$.

After performing and evaluating all analyzes, it can be stated that even if the market share of radios in the market for listening has its own development assessed on its own parameters, the market for advertising on these radios is comparable with it.

During the monitored period of 2011 to 2015, it is also seen in practice what we have also pointed out with theoretical knowledge. Listeners are the most important part of each radio. Their number and effort to increase them guarantees them positive results in terms of their market share. This is also considered by advertisers and their decision-making on the radio station is clearer and easier.

Both markets are somewhat affected, as can be seen in particular in the radios in both regions. The proportion of ad volume in the watched radio is shown in Figure 3. 


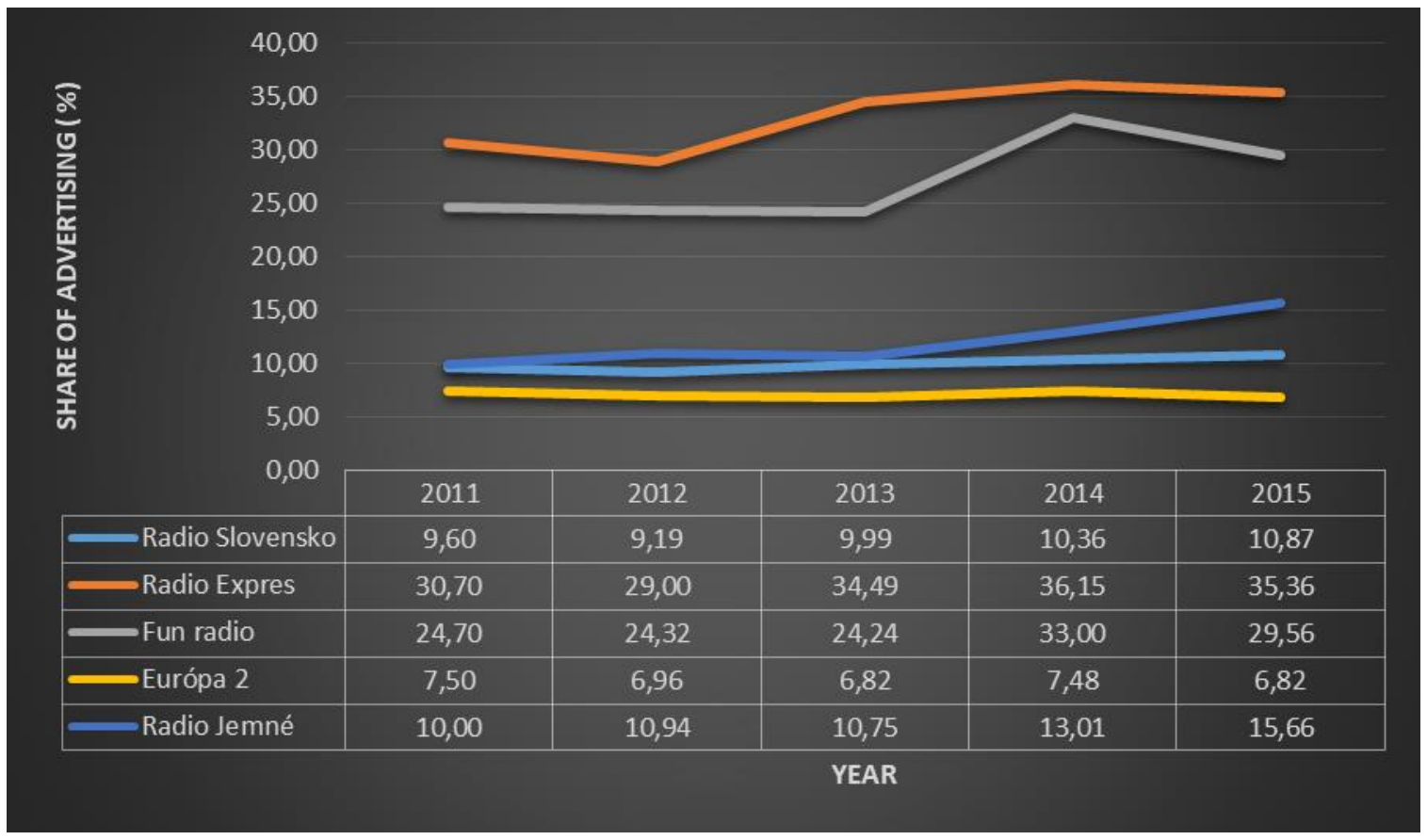

Fig. 3. Overview of the volume of radio advertising in 2011-2015 (\%) Source: Processed from the results of TNS Slovakia, Ltd.

As we already have seen in this discussion, even after the advertising market has suffered from the economic recession and overall decline in marketing investment, we see how the development of radio advertising investment is rising again. For the sake of clarity, using Figure 4, we have attempted to show the specific development of radio advertising investment expressed in exact figures in EUR. 


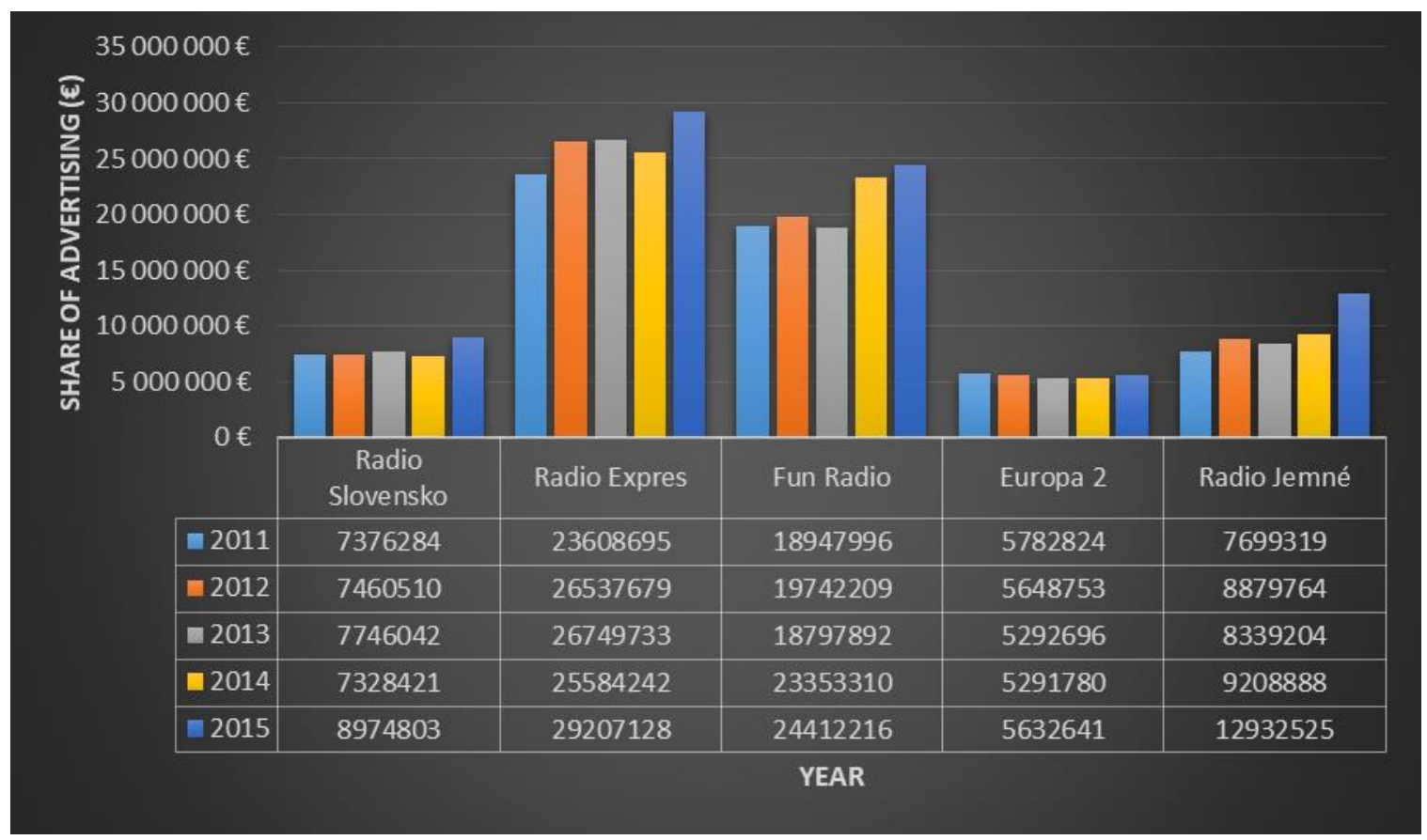

Fig. 4. Overview of the volume of radio advertising in 2011-2015 (€) Source: Processed from the results of TNS Slovakia, Ltd.

\section{Conclusion}

Based on the analysis of the development trends of the selected five Slovakian radios in the Slovak Republic during the monitored period 2011-2015, the radio market was more stable, with the radio stations not ranked in the highest positions. While there have been minor variations in the market share of radio frequencies, whether in decline or increase, the order of these radios has not changed in one year. It can be said that the very success of radio stations to succeed in the market and to achieve a certain market share depends primarily on the size of the market and the number of competitors. Each radio station has its own defined format as well as its target group, and in many cases, these target groups and their age definition are very similar. For this reason, listeners are the most important aspect in determining their share of the radio station market, and are also a magnitude that decides on the decline or increase of the market share of each radio.

In the period under review, following the economic recession and the decline in marketing investments after the financial and economic crisis, we have seen a clear increase in investment in radio advertising. It should be noted that the development of investments in radio advertising influences a number of factors, with priority being not only to the economic and market situation of investors, the development of the economy, but also to the growing number of radio broadcasters and the situation on the media market. It is also necessary to attach great influence to the social behavior (Benda-Prokeinová et al., 2017) and to the continuous development of broadcasting. The radio market is also nowadays requiring ever greater compromises. In many cases, it happens that the radio advertising space is being sold together with another competitive station because advertisers are demanding it from the point of view of the most effective investment of advertising finance in terms of advertising efficiency and targeting the audience. 
The International Journal

ENTREPRENEURSHIP AND SUSTAINABILITY ISSUES

ISSN 2345-0282 (online) http://jssidoi.org/jesi/ 2018 Volume 6 Number 2 (December) http://doi.org/10.9770/jesi.2018.6.2(9)

The media market is one of the most dynamic parts of the economy, as market conditions, media characteristics and audience preferences are constantly changing. For this reason, that radio stations constantly work on their development, broadcast structure, and adapt to the time that influences listeners. By fulfilling these goals, they have a prerequisite not only to keep their listener base, but also to try to increase it.

The beginning of the 21 st century is characterized by a massive increase in information and communication technologies, resulting in the development of network media. Nevertheless, it must be said that radio has a significant place in the media system in the Slovak Republic and will be an important part of the media market in the coming years. In the case of radio, fortunately, the situation is not as dramatic as in the case of declining sales and daily press readings, as confirmed by several studies at home and abroad. (Lincényi, Fabus, 2017)

\section{Acknowledgements}

The paper is the output of a scientific project IGA no. 3/2017 „Development of international business and international management in the conditions of globalization". (Funder: VSEMvs IGA VSEMvs, i.e. School of Economics and Management in Public Administration)

\section{References}

Benda-Prokeinová, R., Dobeš, K., Mura, L., Buleca, J. 2017. Engel's Approach as a tool for estimating consumer behaviour. $E$ \& $M$ Ekonomie a Management, 20(2), pp. 15 - 29

Burton, g., Jirák, j. 2001. Introduction to Media Studies.(Úvod do studia médií.) Praha: Barrister \& Principal, ISBN 978-80-85947-67-6.

Cseh Papp, I., Varga, E., Schwarczová L., Hajós, L. (2018). Public work in an international and Hungarian context. Central European Journal of Labour Law and Personnel Management, 1(1), pp. 6 - 15

Dul'ová Spišáková, E., Mura, L., Gontkovičová, B., Hajduová, Z. 2017. R\&D in the context of Europe 2020 in selected countries. Economic Computation and Economic Cybernetics Studies and Research, 51(4), pp. 243 - 261

Groma, P. 2016. Expenditure on advertising and advertising space in the mass media in the analyzed 55 countries of the European Union and the Slovak Republic, observation of their consequences. Medzinárodné vedecké dni 2016, Nitra, ISBN 978-80-552-1502-0

Kita, J. et. al. 2010. Marketing. Bratislava: Ekonómia, ISBN 978-80-8078-327-3.

Koval'ová, M., Kulčár, L. 2017. Innovation management and information acquisition. Acta Oeconomica Universitatis Selye, 6(2), pp. 101 108

Lincényi, M., Fabuš, M. 2017. Economic trends of business actors on daily newspaper market: case of the slovak republic. Entrepreneurship and sustainability issues, 5(1), pp. 91 - 104. https://doi.org/10.9770/jesi.2017.5.1(7)

MEDIAN SK, MML-TGI. 2011. 1st + 2nd wave 2011 (moving data)

[Online]. 2016 [30.12.2017]. Available on the Internet: https://www.radia.sk/pocuvanost/mml-tgi/vlny/2011-2

MEDIAN SK, MML-TGI. 2011. 3. + 4. vlna 2011 (sliding data)

[Online]. 2016 [30.12.2017]. Available on the Internet: https://www.radia.sk/pocuvanost/mml-tgi/vlny/2011-4

MEDIAN SK, MML-TGI. 2012. 1st + 2nd wave 2012 (sliding data). [Online]. 2016 [30.12.2017]. Available on the Internet: https://www.radia.sk/pocuvanost/mml-tgi/vlny/2012-2

MEDIAN SK, MML-TGI. 2012. 3rd + 4th Wave 2012 (Sliding Data)

[Online]. 2016 [30.12.2017]. Available on the Internet: https://www.radia.sk/pocuvanost/mml-tgi/vlny/2012-4

MEDIAN SK, MML-TGI. 2013. 1st + 2nd wave 2013 (moving data). [Online]. 2016 [30.12.2017]. Available on the Internet: https://www.radia.sk/pocuvanost/mml-tgi/vlny/2013-2 
MEDIAN SK, MML-TGI. 2013. 3rd + 4th 2013 (sliding data)

[Online]. 2016 [30.12.2017]. https://www.radia.sk/pocuvanost/mml-tgi/vlny/2013-4

MEDIAN SK, MML-TGI. 2014. 1st + 2nd wave 2014 (moving data). [Online]. 2016 [30.12.2017]. Available on the Internet: https://www.radia.sk/pocuvanost/mml-tgi/vlny/2014-2

MEDIAN SK, MML-TGI. 2014. 3rd + 4th wave 2014 (moving data)

[Online]. 2016 [30.12.2017]. https://www.radia.sk/pocuvanost/mml-tgi/vlny/2014-4

MEDIAN SK, MML-TGI. 2015. 1st + 2nd wave 2015 (moving data). [Online]. 2016 [30.12.2017]. Available on the Internet: https://www.radia.sk/pocuvanost/mml-tgi/vlny/2015-2

MEDIAN SK, MML-TGI. 2015. 3rd + 4th wave 2015 (moving data)

[Online]. 2016 [30.12.2017]. https://www.radia.sk/pocuvanost/mml-tgi/vlny/2015-4

Mura, L., Ključnikov, A., Tvaronavičiene, M., Androniceanu, A. 2017. Development Trends in Human Resource Management in Small and Medium Enterprises in the Visegrad Group. Acta Polytechnica Hungarica,. 14(7), pp. 105 - 122

Poliačiková, E. 2017. Perception of types of markets of customers in Slovakia. Acta Oeconomica Universitatis Selye, 6(2), pp. 129 - 136

Punch, Keith, F. (a) 2008. Successful research proposal. Praha: Portál, 2008, ISBN 978-80-7367-468-7.

Rublíková, E., Príhodová, I .: Analysis of selected time series - ARIMA models. Bratislava: Ekonóm, 2008. 214 s. ISBN 978-80-225-2540-4

TASR. 2016. SURVEY: Which radios are the most popular in Slovakia? [Online]. 2016 [20.12.2017]. Available on the Internet http://www.teraz.sk/kultura/prieskum-ktore-radia-su-na-slovensk/213954-clanok.html

Tóth, Z., Mura, L. 2014. Support for small and medium enterprises in the economic crisis in selected EU countries. Hradec Economic Days 2014: Economic Development and Management of Regions, PT V, 424-429.

TNS SLOVAKIA. 2015. Advertising Market 2015. [online]. 2016 [30.12.2017]. http://www.tns-global.sk/informacie-pre-vas/tlacovespravy/reklamny-trh-2015

TNS SLOVAKIA. 2014. Advertising Market 2014. [online]. 2016 [30.12.2017]. http://www.tns-global.sk/informacie-pre-vas/tlacovespravy/reklamny-trh-2014-0

TNS SLOVAKIA. 2013. Advertising Market 2013. [online]. 2016 [30.12.2017]. http://www.tns-global.sk/informacie-pre-vas/tlacove$\underline{\text { spravy/reklamny-trh-v-roku-2013 }}$

TNS SLOVAKIA. 2011. Advertising costs in Slovakia grew by 7 percent in 2011, television grew and newspapers declined. [Online]. 2016 [30.12.2017]. https://tlacovespravy.wordpress.com/2012/05/10/tns-slovakia-vydavky-na-reklamu-na-slovensku-vzrastli-v-roku-2011-o-7percent-rastli-televizie-a- declined-newspaper /

Venkatachalam, S., Wong, F., Uyar, E., Ward, S., Aggarwal, A., 2015. Media Company Uses Analytics to Schedule Radio Advertisement Spots. Interfaces, 45(6), pp. 485-500, https://doi.org/10.1287/inte.2015.0825 
Michal FABUS PhD. in International Economics Relations, obtained at University of Economics in Bratislava, currently at Department of Economics and Finance as Head of department, School of Economics and Management in Public Administration in Bratislava (VSEMvs), Slovakia.

ORCID ID: orcid.org/0000-0002-3792-179X

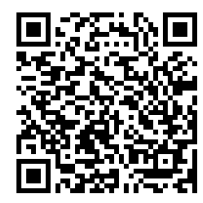

Marcel Lincényi, PhD. in Media studies, obtained at Constantine the Philosopher University in Nitra, currently at Department of Economics and Finance as associate professor, School of Economics and Management in Public Administration in Bratislava (VSEMvs), Slovakia.

ORCID ID: https://orcid.org/0000-0002-9076-026X

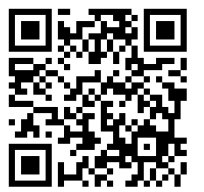

Register for an ORCID ID:

https://orcid.org/register

Copyright (C) 2018 by author(s) and VsI Entrepreneurship and Sustainability Center

This work is licensed under the Creative Commons Attribution International License (CC BY).

http://creativecommons.org/licenses/by/4.0/

C) (i) Open Access 